\title{
Library Use Patterns among Full- and Part-Time Faculty and Students
}

\author{
Jo Bell Whitlatch
}

Trends in higher education are toward part-time students and majors in professional fields which are associated with low library use. Research findings at San Jose University, California, and other academic libraries, demonstrate that declining library use may be a future trend. Declining use will further erode administrative support for library budgets. Libraries must become more effective in identifying and meeting the information needs of new nontraditional students. User surveys establishing service priorities can be an effective tool in planning library service for future student and faculty populations.

peculation concerning the future of libraries has often focused upon the advent of the "paperless society" and the effects of library automation. However, another trend may have a much more immediate and traumatic effect upon libraries in our universities. Several recent trends in higher education enrollments require the academic library to reassess services to a student body no longer composed primarily of full-time students obtaining liberal arts degrees.

Enrollments in universities and colleges in the nation have been shifting toward the professional fields, particularly business and engineering, which rely less on literature and more on experience and handbooks. In the future, several fields are expected to show significant increases in the number of bachelor's degrees: computer and information sciences; business and management; communications; engineering and engineering technologies; health professions; and agriculture and natural resources. Decreases are expected in education, social sciences, letters, library science, mathematics, and statistics.
Full-time white males are now a student minority. Participation in higher education by members of subgroups other than white males has been increasing, ${ }^{2}$ and over the past decade there has been a rise in the number of part-time students at our universities. $^{3}$

Many library studies have demonstrated that libraries are not, and never have been, regularly used by most people. A number of public library user studies have found that the public library is an institution used by a minority of people. ${ }^{4}$ Less well known is the fact that academic libraries also tend to be used by a minority of students. A recent study at DePauw indicates that 40 percent of the student body did not borrow a single library item during the semester ${ }^{5}$ and that 10 percent of the students accounted for almost half of the circulation of all library materials. ${ }^{6}$ Survey results from several academic libraries show that a consistently high percentage of students (from 10.8 percent to 63 percent) do not make use of the library facilities.

Surveys also indicate that the faculty heavily influences student use of the library. Studies by Lolley, Naylor, and Lu-

Jo Bell Whitlatch is access division head, San Jose State University Library, California. 
bans have concluded that the majority of faculty do not expect students to use the library. There is heavy reliance on textbooks and class-distributed materials. Courses that predominantly involve skill development require materials that are readily accessible to the classroom, laboratory, or shop. ${ }^{9}$ The lack of emphasis on library use in the curriculum at the freshman and sophomore levels has been shown to be the major reason why student use of the library is low in the first two years and increases with advances in class standing. ${ }^{10}$ Knapp's study reported that one-quarter of the courses in college accounted for 90 percent of library circulation. ${ }^{11}$ A study by Lubans indicates that a much higher percentage of users ( 40 percent) than nonusers (19 percent) believe that professors encourage students to use the library. ${ }^{12}$ Past studies usually have shown that it is possible to do acceptable college-level work without using the library's resources. ${ }^{13}$ Hardesty has noted that students appear to be using (or not using) the library to the same degree they did more than forty years ago. Classroom teachers have not significantly changed their views toward the library, and librarians have been largely unsuccessful in influencing classroom teachers. ${ }^{14}$

Despite important innovations in library services such as bibliographic instruction and online literature searching, and as enrollment and faculty changes move toward disciplines not relying heavily upon the library for information, library use can be expected to decline in the future. Chen and Hernon believe that the library has lessened its position as an information source by failing to "service knowledge consumers' most basic needs." This undermines the library's claim to public funds. ${ }^{15}$ Without a more complete understanding of the patterns of information need and fulfillment, libraries cannot compete with other information providers in the struggle for survival. The alternative to competition and adaptation is irrelevance, disuse, and organizational decay. ${ }^{16}$ Axford has noted that the serious funding problems of the next decade will inevitably lead to some management concepts infiltrating the budgeting and plan- ning process at all levels of higher education. The most obvious example of this would be market principles that underlie the reluctant shift of resources from the traditional liberal arts programs to the professional schools-the inevitable consequences of enrollment pressures and student-driven budgets. ${ }^{17}$

Specifically, data collected in a study at San Jose State University demonstrate that there are significant differences between part-time and full-time faculty and student use of the library, with part-time students and faculty using the library less. There are also significant differences in library use between faculty and students from the different academic disciplines. Significantly smaller proportions of students and faculty from the professional schools use the library. Data collected in the San Jose study not only confirm the major findings of most of the earlier user studies, but also suggest that enrollment trends and faculty hiring patterns will tend to make the library even more of a "minority" institution on the campus.

San Jose State University is one of the nineteen institutions of higher education in the California State University System. The principal function of the California State University System is to provide both undergraduate and graduate instruction (through the master's degree) in the liberal arts and sciences, in applied fields, and in the professions. San Jose State is one of the larger institutions in the system with 25,000 enrolled students (20 percent are graduate students) and 1,753 faculty ( 900 are tenured or tenure track). Graduate instruction is offered in more than fifty fields. San Jose State is located in the large metropolitan San Francisco Bay area, with a student body sharing many common characteristics of other urban campuses. Many of the students come from nontraditional student populations: poor and lower middle class, older, married, minority and ethnic groups, and students with jobs. At San Jose 40 percent of all students are part-time, with this proportion remaining relatively constant over the past several years. Across the nation the percentage of all faculty members who are employed part-time increased from 22.4 
percent in 1968 to 31.2 percent in $1978 .{ }^{18}$ In the seventies the proportion of part-time faculty also rose steadily at San Jose State. However, due to declining enrollment and high levels of tenured faculty, in the past two years the proportion of part-time faculty has dropped from the $1977 / 78$ high of 37 percent to 27 percent in the spring of 1980. The student body at San Jose reflects the trends in future student populations in urban public universities. Following national trends, 20 percent of all San Jose students are majoring in business; 13 percent in engineering; and 16 percent in applied arts, which includes such areas as nursing, health science, administration of justice, recreation, and journalism. Only 30 percent have majors in the schools of humanities, social sciences, and science. Of the 60 percent tenured faculty at San Jose, more than half have their primary teaching service areas in the schools of humanities, social sciences, and science: only 10 percent are in engineering; 10 percent in business; and 15 percent in applied arts. The library houses 700,000 bound volumes, plus additional microform, media, and curriculum collections.

Because San Jose had been planning a new library which opened in February 1982 , the university authorized the 1980 student and faculty library user surveys in order to assist the library in collecting information regarding student and faculty research and information needs. Student and faculty perceptions concerning the adequacy of library services were useful in planning the new Clark Library. Library "use" and "users" are not well defined. A variety of measures, such as items borrowed, items used in the library, interlibrary loan requests filled, and reference questions answered, have been used to represent "use." "Users" have been represented by terms such as registered borrowers, or persons actually borrowing materials. This study uses a self-report on the frequency of library visits. To obtain data on "general use" of the library, students and faculty were asked how often they usually used the library during a semester. Two other questions were asked of library users through the survey. Respondents were asked if they were satis- fied, dissatisfied, or had never used specific library services such as circulation, periodicals, reference, and government documents. Respondents were also asked if they used other libraries in connection with their San Jose State course work (for students) or teaching and research (for faculty). Therefore, the library user study provided an opportunity to examine the library and responses from its primary community based upon present services offered.

Students numbering 1,470 (5.9 percent of the total student body) were surveyed through a questionnaire given to a random sample of classes. The Testing Office of the university used a standard procedure to obtain the random sample: a schedule of classes in code number order was provided by computing services, and a book of random numbers was used to select a sample from the list. Students sampled were generally representative of the actual proportions of students enrolled by class and major during spring 1980 . The academic vice-president asked all deans and departmental chairpersons to distribute a parallel survey to each of the full-and part-time faculty in their respective areas. Of the 1,753 faculty surveyed, 443 (a 25.3 percent response rate) returned the survey. This response rate, while low, is not atypical for mail surveys. While faculty responses were distributed fairly evenly across all schools, the results probably contain a bias toward frequent library users because of the low response rate from part-time temporary faculty. An analysis of survey responses indicates that a substantial portion of part-time faculty (20 percent) never use the library, compared with only 2.2. percent of the full-time faculty. A much smaller number of temporary faculty, most of whom are also parttime, returned the survey versus tenured or tenure-track faculty. This bias toward the frequent library user is not present in the student results where it is possible to obtain an almost 100 percent response rate through class administration. Verification of the accuracy of questionnaire responses is difficult; however, the questionnaire was pretested in one graduate and two undergraduate library science classes so 
that questions would be designed to avoid misinterpretation of instructions or questions leading to response errors. The data available from the student and faculty surveys were analyzed with the assistance of SPSS frequencies and crosstabs programs.

\section{USER POPULATION CHARACTERISTICS}

As is true in other academic libraries, the recent user survey at San Jose State University reveals relatively low general use of the library; 12.2 percent of the students never use the library, while only 29.6 percent use the library once a week or more during the semester. Use by faculty is also fairly low, 31.9 percent use the library once a week or more, and 5.2 percent never use the library. The majority of faculty (62.2 percent) rely on purchased books and periodicals as their primary source of information for teaching and research, while only 29.1 percent rely on the library as their primary source.

Surveys conducted in other libraries have found the percentage of part-time students who did not use academic libraries as high as 50 percent $^{19}$ and as low as 25 percent. ${ }^{20}$ Pritchard and Payne also found that part-time students who attended classes during the day were more likely to use the library than evening students. ${ }^{21}$

As illustrated in table 1, students seldom or never using San Jose State University Library are more likely to be evening students, part-time, female, and white or black rather than other ethnic groups. Students using the library frequently are more likely to be enrolled full-time and from Asian or Chicano ethnic backgrounds. Results from the faculty survey, illustrated in table 2, reveal that faculty seldom or never using the library are more likely to be evening instructors, part-time, and temporary. Faculty using the library frequently are more likely to be full-time, tenure-track, and teach classes primarily during the day. While 34.7 percent of all full-time students seldom or never use San Jose State University Library, almost half (45.8 percent) of all part-time students seldom or never use the library. A New
York University survey found that 57 percent of all students used the library at least once weekly; ${ }^{22}$ only 29.6 percent of all San Jose students use the library weekly. At the time of the survey only 26 percent of the New York University student body was part-time, ${ }^{23}$ while 40 percent of San Jose's students are part-time. The San Jose data support previous research findings on low library use by part-time students. The number of part-time students in a university appears to decrease the level of library use significantly.

Declining use levels may be slightly offset by the increase in non-white ethnic populations, particularly in areas having high concentrations of Asian students. One of the most interesting results of the San Jose study is the significantly higher frequency of library use by Asians and Chicanos compared to other ethnic groups (see table 1). A recent study on the information needs of Californians found that Asians were highest in their use of libraries as information sources, ${ }^{24}$ and that Hispanics have the largest proportion who never use a library to seek information. ${ }^{25}$ In the case of San Jose's Chicano students, other factors such as educational level must affect informationseeking patterns more than ethnic background.

As with other urban campuses, San Jose State students have convenient access to many other alternative resources. Other libraries are an important resource for San Jose State faculty and students; 57.5 percent of students and 70.2 percent of faculty reported that other libraries are used during the semester in connection with San Jose State course work for teaching, study, and research. There are no significant differences between part- and fulltime or day and evening students. Faculty using other libraries are more likely to be full-time, male, and tenured or tenuretrack, but differences between day and evening teachers, while significant, are very small. Although Gocek does not find geographic proximity to be the major determinant of use, ${ }^{26}$ it is difficult to measure, and others have found that it does play a role. Extension and commuting students are more inclined to use libraries 
TABLE 1

LIBRARY USER PATTERNS: STUDENT POPULATION CHARACTERISTICS $(N=1,470)$

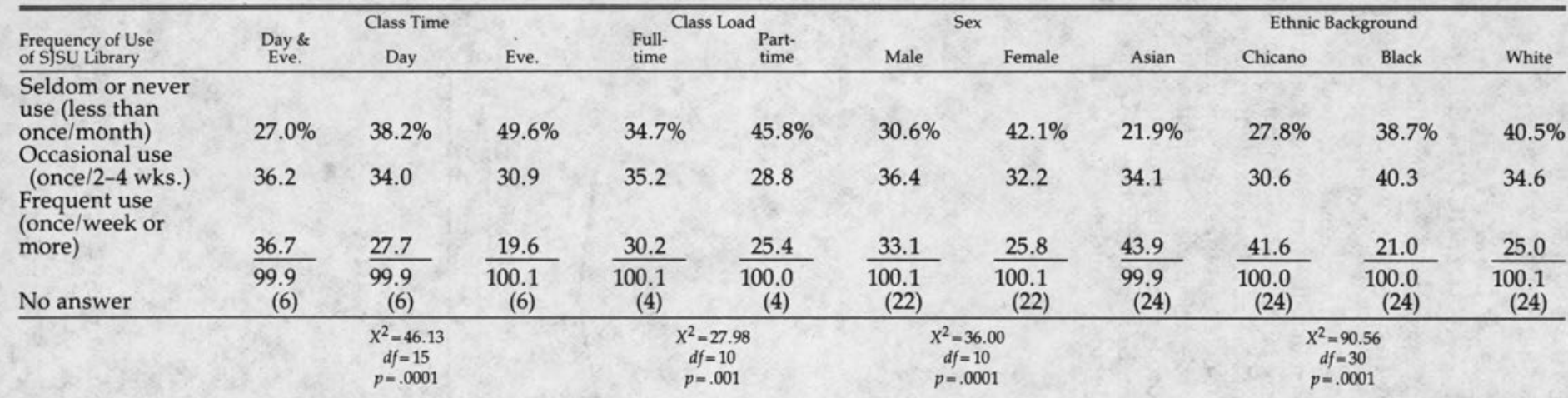

TABLE 2

LIBRARY USER PATTERNS: FACULTY POPULATION CHARCTERISTICS $(N=443)$

\begin{tabular}{|c|c|c|c|c|c|c|c|c|c|}
\hline \multirow[b]{2}{*}{$\begin{array}{l}\text { Frequency of Use } \\
\text { of S)SU Library }\end{array}$} & \multicolumn{2}{|c|}{ Teaching Time } & \multicolumn{2}{|c|}{ Teaching Load } & \multicolumn{2}{|c|}{ Sex } & \\
\hline & Day & Eve. & $\begin{array}{l}\text { Full- } \\
\text { time }\end{array}$ & $\begin{array}{l}\text { Part- } \\
\text { time }\end{array}$ & Male & Female & Tenured & $\begin{array}{l}\text { Tenure- } \\
\text { Track }\end{array}$ & Temporary \\
\hline $\begin{array}{l}\text { Seldom or never } \\
\text { use (less than }\end{array}$ & & & & & & & & 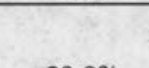 & \\
\hline $\begin{array}{l}\text { once/month) } \\
\text { Occasional use }\end{array}$ & $21.7 \%$ & $34.3 \%$ & $19.8 \%$ & $42.7 \%$ & $21.5 \%$ & $29.6 \%$ & $15.6 \%$ & $20.9 \%$ & $45.4 \%$ \\
\hline (once/2-4 wks.) & 43.8 & 46.1 & 46.8 & 33.3 & 44.5 & 44.3 & 50.0 & 34.9 & 33.3 \\
\hline $\begin{array}{l}\text { Frequent use } \\
\text { (once/week or } \\
\text { more) }\end{array}$ & 34.5 & 19.7 & $\underline{33.3}$ & 24.0 & 34.0 & 26.2 & 34.4 & 44.2 & 21.3 \\
\hline No answer & $\begin{array}{r}100.0 \\
(11)\end{array}$ & $\begin{array}{r}100.1 \\
(11) \\
\end{array}$ & $\begin{array}{r}99.9 \\
(5)\end{array}$ & $\begin{array}{r}100.0 \\
(5)\end{array}$ & $\begin{array}{r}100.0 \\
(9)\end{array}$ & $\begin{array}{r}100.1 \\
(9)\end{array}$ & $\begin{array}{r}100.0 \\
(114)\end{array}$ & $\begin{array}{c}100.0 \\
(114)\end{array}$ & $\begin{array}{c}100.0 \\
(114) \\
\end{array}$ \\
\hline & & & & & & & & $\begin{array}{c}X^{2}=247.26 \\
d f=18 \\
p=.0001\end{array}$ & \\
\hline
\end{tabular}


close to their homes than dormitory or nearby campus residents. ${ }^{27}$ Of San Diego State University Library nonusers who used other college libraries, 91.7 percent indicated that those libraries were closer to their homes. ${ }^{28}$

However, many frequent San Jose State students and faculty library users also used other libraries once a week or more (see figure 1). Only 10-20 percent of the students, but 40 percent of the faculty, who seldom use San Jose State University Library frequently use other libraries. Although few students and a substantial number of faculty who never use San Jose State University Library appear to use other libraries, frequent San Jose State Li- brary users visit other libraries as a supplement to San Jose's resources.

\section{LIBRARY USE BY ACADEMIC DISCIPLINE}

Investigators have found that business and engineering undergraduates make relatively low use of the library. ${ }^{29}$ Disciplines in the humanities and social sciences usually account for the bulk of library circulation. ${ }^{30}$ The San Jose survey confirms results obtained from studies conducted at other academic libraries. Academic discipline is a significant variable in the level of general use of the San Jose State University Library. (See table 3.)

Business students and business, ap-

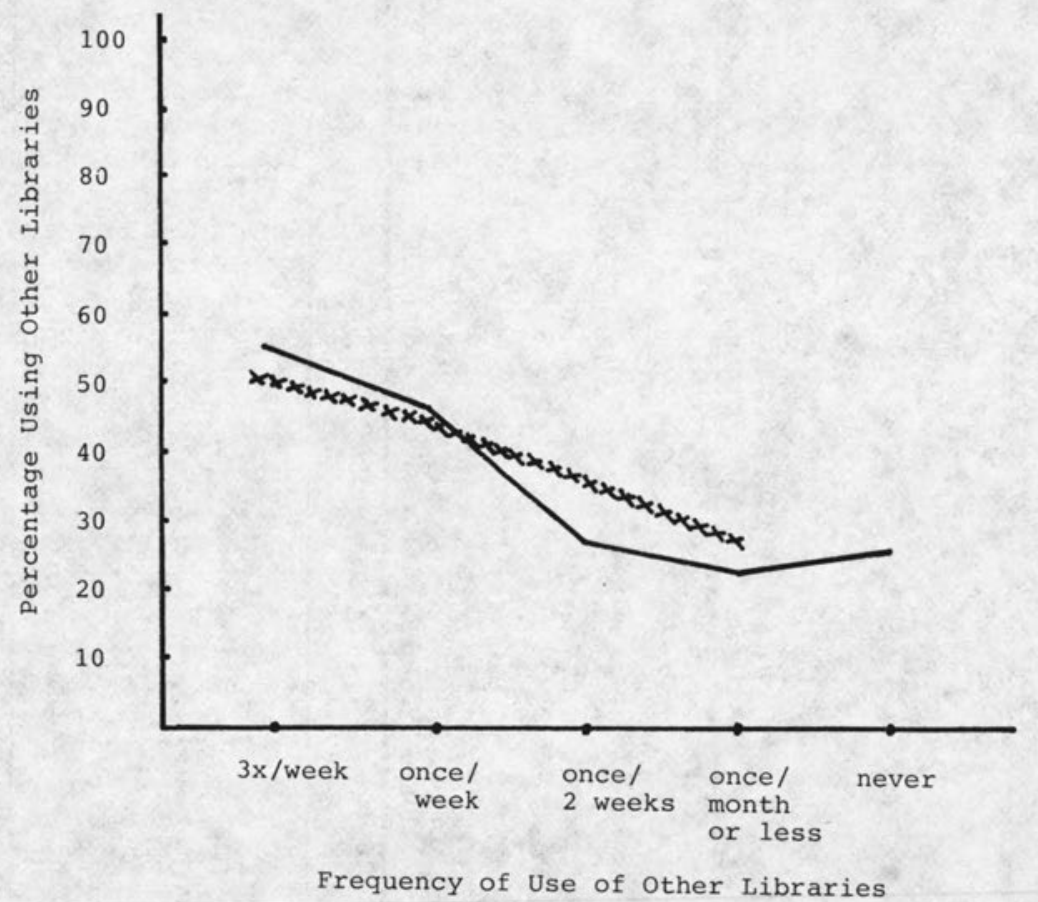

Students Using SJSU Library Once/Week or More

xxxxxxxxxxxx Faculty Using SJSU Library Once/Week or More 


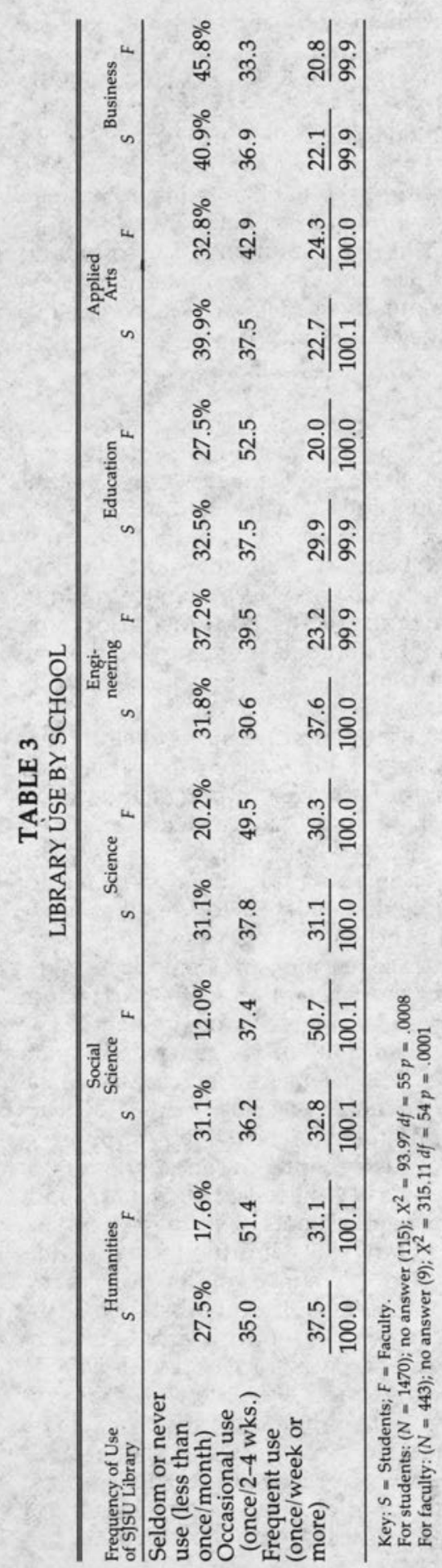

plied arts, and engineering faculty were least likely to use the library. Business, applied arts, and engineering faculty also had high proportions of temporary faculty (42.9 percent, 25.0 percent, 51.2 percent), while other schools averaged 15-17 percent. Since survey results indicated that temporary faculty are less likely to use the library (see table 2 ), the high proportions of temporary faculty in business, applied arts, and engineering further decrease the use of the library in these disciplines. Therefore, discipline is a more important variable than part-time status. This is somewhat difficult to determine because the numbers of temporary faculty underrepresented the faculty respondents. Temporary and part-time status do not have a uniform influence across schools. Despite the high proportion of temporary faculty in applied arts (42.9 percent) relative to business ( 25 percent), applied arts still has a much lower proportion of faculty who seldom or never use the library (see table 3). Also, a much higher proportion of part-time students seldom or never use the library (see tables 1 and 2). However, schools with the greatest proportion of part-time students (education, 31.2 percent, and social science, 17.2 percent) have much smaller proportions of students seldom or never using the library (32.5 percent and 31.1 percent as noted in table 3) than applied arts, where only 7.7 percent of students are part-time, but 39.9 percent seldom or never use the library. Social science faculty was the only group with more than half of its population using the library once a week or more.

Use of specific services within the library, such as current periodicals and reference, was also examined to determine how their use related to general use of the library. As noted earlier in table 3, general use of the library was usually lower in the professional schools. A much lower proportion of students and faculty in the professional schools tends to use the major types of information services presently offered by the library.

Faculty and students were also asked to rate the importance of San Jose State University Library as a source of information for studies (students) or research and 
teaching (faculty). Respondents were asked to rank San Jose State University Library relative to a popular book or magazine, a colleague (for faculty), a professor (for students), or another library. Less than half of the engineering, science, business, and applied arts students ranked San Jose State University Library in their top two choices, as did a similar percentage of business, applied arts, education, and engineering faculty.

Some improvement in use of services could be made by strengthening book and periodical collections in the applied arts, since the highest proportion of students desiring more new books and periodical subscriptions are enrolled in applied arts. However, students and faculty in some professional schools do not appear to be greatly interested in strengthening the traditional library services. Engineering faculty and students have the lowest rate of interest in acquiring new books and periodicals.

Only 58.6 percent of San Jose students think that faculty in their major field are familiar with the library. The highest proportion of students stating that library resources are frequently required for study and research are majors in the schools of education, humanities, and social sciences (see table 4).

Thus, results at San Jose, as well as findings in other academic library studies, in-

\section{TABLE 4}

STUDENTS AND FACULTY INDICATING THAT COURSES IN MAJOR AREA FREQUENTLY REQUIRED USE OF THE LIBRARY FOR STUDY AND RESEARCH

\begin{tabular}{|c|c|c|}
\hline School & $\begin{array}{l}\text { Students } \\
(N=1470)\end{array}$ & $\begin{array}{l}\text { Faculty } \\
(N=443)\end{array}$ \\
\hline Education & $37.5 \%$ & $35.0 \%$ \\
\hline Humanities & 30.8 & 33.8 \\
\hline Social science & 29.3 & 30.7 \\
\hline Applied arts & 26.2 & 41.4 \\
\hline Science & 19.3 & 24.2 \\
\hline Business & 15.6 & 29.2 \\
\hline Engineering & 7.0 & 11.6 \\
\hline No answer & (125) & (11) \\
\hline & $\begin{array}{c}X^{2}=144.32 \\
d f=44 \\
p=.0001\end{array}$ & $\begin{array}{c}X^{2}=111.65 \\
d f=36 \\
p=.0001\end{array}$ \\
\hline
\end{tabular}

Note: Students and faculty were asked how often assignments in courses involved using library resources other than materials on reserve. Possible choices were: frequently, sometimes, rarely, never. dicate that faculty and students in professional programs, such as business and engineering, tend to make less use of the library than students and faculty in the traditional liberal arts programs, particularly in social sciences and the humanities. Therefore, the national shift from liberal arts to professional fields in student majors is likely to result in less use of library resources and more graduates who have not regularly used libraries as part of their college education.

\section{CONCLUSIONS}

We can expect use of academic library collections and resources to decline because of (1) the trend toward part-time students and (2) majors in disciplines that are generally correlated with low library use. Libraries are already having serious budget problems. Declining use could be devastating if the administration considers the library less essential to the university, and therefore a logical area to cut funds.

Librarians must assume a leadership role in developing student skills in library and information use as part of undergraduate instruction. A vigorous and aggressive bibliographic instruction program that reaches out to all students and faculty is an obvious answer to low library use and has been much discussed in the literature. Colleges and universities across the nation are reexamining the curriculum and resurrecting core requirements. The new national interest in general education can serve as a vehicle to increase use of the library if an active bibliographic instruction program is developed as an integral part of the general education program of the university. In reviewing general education requirements, weaknesses in student library skills and the increasing importance of these skills for many occupations as well as understanding current developments have been noted. ${ }^{31} \mathrm{Ob}$ jectives of the California State University System general education program include ". . . to find and critically examine information .... and .... an understanding and appreciation of principles, methodologies, value systems, and thought processes employed in human in- 
quiries." San Jose has developed a library instruction program as part of the general education lower- and upper-division writing requirements. Since the lowerdivision unit was implemented prior to this survey, and the upper-division unit during fall 1981, the results of this survey can be used as baseline data for future evaluation of the bibliographic instruction program.

An active bibliographic instruction program may influence faculty attitudes toward library use. In the United States, the tradition in faculty teaching does not involve extensive use of the library nor encourage students to use the library to formulate research topics or independent inquiries. Faculty usually direct the readings or identify topics of inquiry in seminars. Studies have suggested that research findings are not a major source of information; that local or informal contacts are common sources of new ideas; ${ }^{32}$ and that libraries are regarded as sources of further information once a research topic has been identified. ${ }^{33}$ Further evidence that faculty do not normally require library use for courses is supported by a finding that there is little relationship between academic achievement and library use. One study did find that as a student's grade point average rose, so did the reported use of the library; ${ }^{34}$ however, the data collected at San Jose do not confirm this thesis. Respondents were asked to list their grade point averages. Based upon self-reported grade point averages, library use appears to have little relationship to $A$ (4.0), $B(3.0)$, or $C(2.0)$ grade point averages, although there is a significant difference between very poor academic students (below 2.0) and others.

This academic tradition in teaching will be very difficult to change. However, incorporating required library instruction into both lower- and upper-division general education writing requirements as San Jose has done, should have several positive effects. At the very least, the program will encourage faculty members to identify the library as a more frequent source of information on designated research topics. Future faculty, who discovered the use and value of library resources as students, will be more likely to incorporate use of library resources into courses they teach. Librarians and faculty, through working together, particularly in the upper-division general education programs for majors in professional fields, have the opportunity to determine whether the professional programs simply do not require the same level of library resources as the humanities and social sciences or whether low use is a symptom that the information needs are strong, but not met by existing library services. Thus, a bibliographic instruction program could contribute to changing the teaching tradition.

However, bibliographic instruction is not a sufficient solution. Research on information-seeking patterns has generally concluded that cost to the user is the most important factor in determining the source of information selected. Cost to the user has been identified as the value of the user's time-in terms of the user's perceptions of the convenience and efficiency of library services. ${ }^{35}$ Studies have identified the lack of time as the principal reason for nonuse, particularly among the employed, ${ }^{36}$ part-time, ${ }^{37}$ and evening students. ${ }^{38}$ A 1976 New York University survey reported that time, difficulty in obtaining materials, purchasing materials, and lack of need for library materials were the principal reasons for infrequent use. ${ }^{39}$ When material is needed to obtain information, Californians are most likely to buy or subscribe to the material. ${ }^{40} \mathrm{Na}$ tionwide survey results indicate that book readers purchased their own books or borrowed them from a friend more often than they borrowed them from a library. ${ }^{41}$

There is some evidence that larger libraries create greater difficulties in locating materials. Commuting students with limited time expressed preference for the public library despite limited collections. ${ }^{42}$ In one area, smaller polytechnic libraries received higher use despite shorter evening hours.

Results at San Jose confirm the general findings from other libraries that lack of need and cost to the user are the two principal reasons for low use. The greatest proportion of students reported no need 
STUDENTS
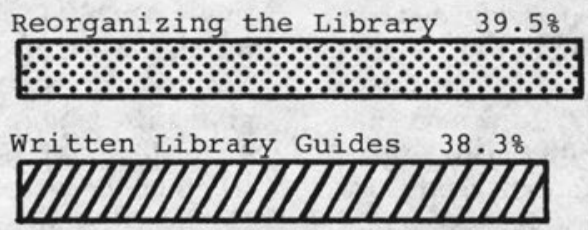

Ordering New Books $38.3 \%$

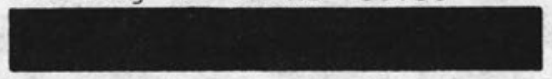

Shelving $36.1 \%$

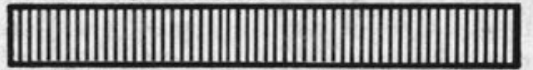

FACULTY

Ordering New Books $56.1 \%$

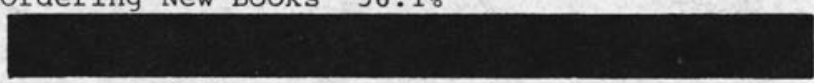

Security of Materials $52.2 \%$

\section{poriodical subsorititions 44.98 Ð}

Shelving $43.2 \%$

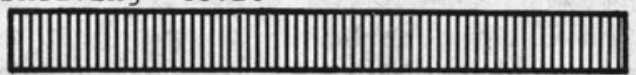

Other service improvements not listed among the top four choices of students or faculty were: extended hours, telephone renewal, automating circulation, personal security, staff help in bookstacks and at service desks, closed periodical stacks, and discarding outdated materials.

FIGURE 2

Service Improvements: Student and Faculty User Priorities

(38 percent), followed by poor organization of the library ( 26 percent), and greater convenience of another library (11 percent). Of the faculty who never or seldom use the library, the majority gave as the reason greater convenience of another library ( 38 percent), followed by no time ( 23 percent), no need ( 21 percent), and poor organization of the library ( 15 percent).

Library hours do not appear to be a primary reason for low use. The San Jose study confirms the results of the New York University survey finding that frequent users were most dissatisfied with library hours. ${ }^{44}$ At San Jose, 43.6 percent of students who used the library three times a week or more believed that the library hours were not always adequate. A much higher proportion of evening students (48 percent) indicated that library hours were not always adequate than did day students ( 26.7 percent). But a slightly smaller percentage of evening students ( 22 percent) rated extended hours as a very important service improvement than did daytime students (25.5 percent). An increase in the main library hours, now seventy-seven hours per week during the semester (excluding reserve), appears more likely to increase use by already frequent users rather than attracting the nonuser. 
Because survey results indicate that the greater convenience of another library in a large urban area determines use, it is particularly desirable to strengthen direct reciprocal borrowing and access programs between institutional libraries. Such programs should then be supplemented by further identification of special collections in the area and planned regional cooperative collection development programs between public, special, and academic libraries.

In the San Jose survey, students and faculty were asked to rate certain possible improvements in library services as "very important," "important," "not important," or "no opinion." Given the existing knowledge about the nature of information-seeking patterns, it can be presumed that students and faculty would rate most highly those service improvements perceived to reduce the cost (i.e., effort) to themselves as users. Continuing nationwide declines in budgetary support to libraries, as well as other educational and public service institutions, will make offering service improvements difficult. Therefore, it is discouraging to note the difference in student and faculty user priorities (see figure 2). The top four choices of the faculty tend to focus on the acquisition, preservation, and maintenance of the book and periodical collections, whereas students give equal priority to improved orientation and organization and the ordering of new books. Both faculty and students do rate improvements in reshelving of materials and acquisition of new books as top choices. In summary, besides a strong library instruction program, academic libraries need to identify top user priorities and focus on improving these services. The San Jose State University Library might best encourage use through reducing costs to both faculty and student users by attempting to improve the current acquisition and reshelving rates for library materials. Since book budgets are declining, it will be important to consider historical and future trends in use of library materials when selecting current acquisitions.

Despite current developments in library automation, library research is still a timeconsuming, labor-intensive effort for the individual user. User surveys that establish user priorities for service improvements and common priorities of different user groups can be an effective tool. Technology has contributed to reducing user effort in such areas as online literature searching and automated circulation systems. However, the new technology is often available in such areas as online searching only for a fee. Databases in disciplines that make extensive use of the library, humanities and history, are still largely undeveloped because of limited business, defense, or government funds for investment in these areas. Investment in top-priority user service improvements should make the use of the library less costly for most users, thus enabling the library to be a major information resource, if not the "heart of the university," for an increased number of students and faculty.

\section{REFERENCES}

1. Martin M. Frankel and Debra E. Gerald, Projections of Education Statistics to 1988-89 (Washington, D.C.: National Center for Education Statistics, 1980), p.56-59.

2. "How Changes in Enrollment Will Affect Higher Education," Today's Education 70:57 (Feb.-March 1981).

3. Allan W. Ostar, "Part-time Students: The New Majority for the 1980 's," Chronicle of Higher Education 23:56 (Oct. 7, 1981).

4. W. Lyle Eberhart, "A Closer Look: Gallup Survey of American Adults Assesses the Role of Libraries in America," American Libraries 7:206-7 (April 1976).

-5. Larry Hardesty, Student Use of the Libraries at DePauw University (ED 187 335) (1980), p.5.

6. Ibid., p.11.

7. Harold Mendelsohn and Karen Wingerd, The Use of Libraries and the Conditions That Promote Their 
Use (ED 022 489) (Washington, D.C.: National Advisory Commission on Libraries, 1967), p.i-36.

8. Alice P. Naylor, Survey of Faculty Expectations: Student Homework (ED 097 027) (Toledo, Ohio: University of Toledo, 1974), p.2.

9. John L. Lolley, Vocational Teachers and the College Library (ED 188704$)$ (1980), p.6.

10. John Lubans, Jr., A Look at Library Use Instruction Programs: The Problems of Library Users and NonUsers (ED 093 311) (Boulder, Colo.: Colorado University Libraries, 1972), p.10.

- 11. Mendelsohn and Wingerd, The Use of Libraries, p.i-35.

12. John Lubans, Jr., "Library Use Instruction Needs from the Library Users'/Nonusers' Point of View: A Survey Report,"' in his Educating the Library User (New York: Bowker, 1974), p.408.

13. Mendelsohn and Wingerd, The Use of Libraries, p.i-32.

14. Hardesty, Student Use, p.34.

15. Ching-chih Chen and Peter Hernon, Information Seeking (New York: Neal-Schuman, 1982), p.xiii.

16. Ibid., p.7.

17. H. William Axford, "Collection Management: A New Dimension," Journal of Academic Librarianship 6:326 (Jan. 1981).

18. "How Changes in Enrollment Will Affect Higher Education," p.57-58.

19. Alan Pritchard and Philip Payne, Part-time Students: Their Use of a Polytechnic Library (ED 191489 ) (London: City of London Polytechnic Library and Learning Resources Service, 1980), p.16.

20. Larry Orton and John Wiseman, "Library Service to Part-time Students," Canadian Library Journal 34:25 (Feb. 1977).

21. Pritchard and Payne, Part-time Students, p.23.

22. "Elmer Holmes Bobst Library: A User Survey; Spring 1976," in Association of Research Libraries, comp., User Surveys and Evaluation of Library Services (Washington, D.C.: The Association, 1981), p.18.

23. Ibid., p.17.

24. California State Library, California's Governor's Conference on Libraries and Information Services, Information Needs of Californians (1979), p.3-4.

25. Ibid., p.5.

26. Matilda A. Gocek, Library Services for Commuting Students (ED 037 228) (Poughkeepsie, N.Y.: Southeastern New York Library Resources Council, 1970), p.14-15.

27. Pamela Reeves, Library Services for Nontraditional Students: Final Report (ED 184 550) (Ypsilanti, Mich.: Eastern Michigan University, 1979), p.13.

.28. Mary Ada Burns, The Relationship between the Use of the San Diego State University Library and Selected Personal Characteristics of the Student Population (ED 154 807) (1977), p.32.

29. John Lubans, Jr., "Student Use of a Technological Library," International Association of Technological University Proceedings 4:12 (July 1969); and Lou Ellen Crawford, Confirmation and Interpretation of Student Attitudes toward the Library at the University of Colorado, Colorado Springs (ED 167 148) (1977), p.19.

30. Hardesty, Student Use, p.15.

31. Carnegie Foundation for the Advancement of Teaching, Missions of the College Curriculum (San Francisco: Jossey-Bass, 1977), p.11.

32. Carl H. Rittenhouse, "Educational Information Uses and Users," A V Communication Review 19:77 (Spring 1971).

33. Barbara Skelton, "Scientists and Social Scientists as Information Users," Journal of Librarianship 5:144 (April 1973).

34. Lubans," Student Use," p.10.

35. Yale M. Braunstein, "Costs and Benefits of Library Information: The User Point of View," Library Trends 28:80 (Summer 1979).

36. Alice P. Naylor, Survey of Student Life Patterns at the Community and Technical College (ED 097020$)$ (Toledo, Ohio: University of Toledo, 1974), p.7.

37. Orton and Wiseman, "Library Service," p.25.

38. Crawford, Confirmation and Interpretation of Student Attitudes, p.19.

39. "Elmer Holmes Bobst Library," p.18.

40. Information Needs of Californians, p.4.

41. Eberhart, "A Closer Look," p.207.

42. Gocek, Library Services, p.19.

43. Pritchard and Payne, Part-time Students, p.21.

44. "Elmer Holmes Bobst Library," p.26. 